\title{
PENGARUH VARIASI FAS DAN KADAR SEMEN PADA \\ KUAT TEKAN MORTAR DAN KUAT TEKAN BETON MENGGUNAKAN PASIR SUNGAI KAHAYAN DI KOTA PALANGKA RAYA
}

\author{
Annisa Wulandari ${ }^{1}$, Maryanto ${ }^{2}$, dan Frieda ${ }^{3}$ \\ ${ }^{123}$ Program Studi Teknik Sipil, Fakultas Teknik, Universitas Palangka Raya \\ E-mail: annisawullan@gmail.com ${ }^{1}$, maryanto@eng.upr.ac.id ${ }^{2}$, dan \\ frieda@jts.upr.ac.id ${ }^{3} /$ HP.+6285220311353 ${ }^{1}$
}

\begin{abstract}
ABSTRAK
Pasir Sungai Kahayan merupakan material agregat halus yang masih digunakan dalam pembuatan beton di Kota Palangka Raya. Penelitian sebelumnya menunjukkan bahwa berdasarkan mix design standar SNI target kuat tekan beton sulit dicapai untuk beton berpasir Sungai Kahayan dalam kelas beton mutu normal tanpa bahan tambah. Penelitian ini mengembangkan penelitian sebelumnya, lokasi sumber pasir berdekatan. Tujuan penelitian ini adalah mengetahui karakter perubahan campuran mortar dan beton, akibat (1) Variasi FAS (faktor air semen) dan (2) Perubahan kadar semen. Perlakuan pengujian ditujukan untuk mempelajari pengaruh sifat mortar terhadap sifat beton. Eksperimen dilakukan terhadap silinder uji (diameter/tinggi): (a) mortar $5 / 10 \mathrm{~cm}$ dan (b) beton $15 / 30 \mathrm{~cm}$. Mutu beton rancangan terbagi atas 3 (tiga) yaitu $20 \mathrm{MPa}, 22,5 \mathrm{MPa}$, dan $25 \mathrm{MPa}$. Perlakuan air campuran terbagi 2 (dua) yaitu (a) FAS tetap (konstan) pada 0,5 dan (b) FAS berubah (variatif) yang dihasilkan dari penambahan semen 10\%, 20\%, $30 \%, 40 \%$ dan pengurangan semen $5 \%$ dan $10 \%$. Hasil penelitian menunjukkan karakter perubahan campuran mortar dan beton akibat variasi FAS dan perubahan kadar semen adalah serupa. Kuat tekan meningkat seiring penurunan FAS dan penambahan kadar semen, demikian sebaliknya penurunan kuat tekan terjadi pada saat nilai FAS meningkat dan kadar semen berkurang. Dengan upaya yang telah dilakukan untuk pencapaian peningkatan kuat tekan dengan perlakuan penurunan FAS (hingga 0,357 dari 0,50) dan penambahan semen (hingga 40\% dari kadar semen standar), kuat tekan target mortar dan beton yang menggunakan pasir penelitian belum dapat diperoleh.
\end{abstract}

Kata Kunci: Faktor Air Semen (FAS), Mortar, Pasir Sungai Kahayan, Beton Mutu Normal

\begin{abstract}
Kahayan River sand is a fine aggregate material that is still used in the manufacture of concrete in Palangka Raya. Previous research has shown that based on the standard SNI mix design, the target concrete compressive strength is difficult to achieve for sandy concrete of the Kahayan River in normal concrete qualities without added materials (admixtures). This study develops previous research, the location of the sand source is close together. The purpose of this study was to determine the character of changes in the mixture of mortar and concrete, as a result of (1) w/c variation (water-cement ratio) and (2) changes in cement content. The test treatment is intended to study the effect of mortar
\end{abstract}


properties on concrete properties. Experiments were carried out on the test cylinder (diameter/height): (a) $5 / 10 \mathrm{~cm}$ mortar and (b) $15 / 30 \mathrm{~cm}$ concrete. The quality of the design concrete is divided into 3 (three), which is $20 \mathrm{MPa}, 22.5$ $M P a$, and $25 \mathrm{MPa}$. The mixed water treatment is divided into 2 (two), that is (a) $w / c$ remains (constant) at 0.5 and $(b) W / C$ changes (varied) resulting from the addition of cement 10\%, 20\%, 30\%, 40\% and reduction of cement $5 \%$ and $10 \%$. The results showed that the character of changes in the mixture of mortar and concrete due to $w / c$ variations and changes in cement content were similar. The compressive strength increases with the decrease in $w / c$ and the addition of cement content, on the other hand the decrease in compressive strength occurs when the $w / c$ value increases and the cement content decreases. With the efforts that have been made to achieve an increase in compressive strength with $w / c$ reduction treatment (up to 0.357 from 0.50 ) and the addition of cement (up to $40 \%$ of the standard cement content), the target compressive strength of mortar and concrete using research sand has not been obtained.

Keywords: Water/Cement Ratio (w/c), Mortar, Kahayan River Sand, Normal Concrete Strength

\section{PENDAHULUAN}

Hingga saat ini pasir Sungai Kahayan masih digunakan sebagai agregat halus dalam pembuatan beton. Diketahui dari penelitian terdahulu, Mariati (2015), bahwa beton dengan Pasir Sungai Kahayan menggunakan mix design standar SK.SNI.T 15-1990-03 belum dapat memenuhi target kuat tekan rencana. Melanjutkan penelitian tersebut, pada penelitian ini akan dilakukan penelitian beton mutu normal sesuai campuran rancangan SNI 03-2834-2000 untuk kuat tekan rencana $20 \mathrm{MPa}, 22,5 \mathrm{MPa}$, dan $25 \mathrm{MPa}$. Tujuan penelitian ini adalah mengetahui sifat fisik dan karakteristik pasir Sungai Kahayan dalam campuran mortar dan beton, mengetahui nilai kuat tekan mortar dan beton, mengetahui pengaruh variasi FAS pada kuat tekan mortar dan beton, serta mengetahui hubungan kuat tekan mortar terhadap kuat tekan beton yang menggunakan pasir Sungai Kahayan. Perlakuan variasi FAS ditujukan untuk mengetahui nilai FAS yang terbaik terhadap campuran rancangan. Perlakuan penambahan/pengurangan semen ditujukan untuk mengetahui kecukupan semen untuk menyusun kekuatan pasta dan kekuatan ikatan interface agregat terhadap pasta dalam tinjauan jumlah pasir dan agregat campuran rancangan. Hal ini dikarenakan, pada beton dengan mutu tinggi saat diberi pembebanan, celah retak tidak terjadi pada bagian mortar melainkan pada ikatan interface agregat kasar dan pasta (Li, hal. 271, 2011). Perlakuan pengujian ditujukan untuk mempelajari pengaruh sifat mortar terhadap sifat beton dan untuk mengetahui hubungan antar sifat kuat tekan mortar terhadap sifat kuat tekan betonnya. Diketahui bahwa kekuatan mortar memiliki pengaruh yang besar pada kekuatan beton mutu normal dilihat dari adanya korelasi linier yang baik dengan koefisien korelasi yang tinggi antara kedua kuat tekan tersebut (Camoes, Aguiar, \& Jalali, 2005).

\section{Persiapan Bahan}

\section{METODE PENELITIAN}

Bahan yang digunakan dalam penelitian ini terdiri dari:

1. Semen Portland Komposit (PCC) dengan merk dagang Gresik. 
2. Agregat kasar batu pecah asal Kelurahan Tangkiling, Palangka Raya.

3. Pasir alami Sungai Kahayan, Palangka Raya.

4. Air sumur bor Laboratorium Struktur dan Bahan.

\section{Peralatan Penelitian}

a. Peralatan yang digunakan untuk pemeriksaan bahan/material dan pengujian beton dalam penelitian adalah peralatan standar Laboratorium Struktur dan Bahan Jurusan Teknik Sipil Fakultas Teknik Universitas Palangka Raya.

b. Peralatan pembuatan benda uji.

1. Cetakan benda uji mortar. Silinder ukuran diameter $5 \mathrm{~cm}$, tinggi $10 \mathrm{~cm}$. Cetakan dibuat dari pipa paralon yang dimodifikasi.

2. Cetakan benda uji mortar. Silinder ukuran diameter $15 \mathrm{~cm}$, tinggi $30 \mathrm{~cm}$.

\section{Tahap Penelitian}

Spesimen uji untuk setiap variasi pada penelitian ini terdiri dari mortar (diameter/tinggi, 5/10 cm) berjumlah 6 buah dan beton (diameter/tinggi, 15/10 $\mathrm{cm}$ ) berjumlah 3 buah. Jenis penelitian yang digunakan adalah metode eksperimen atau percobaan di Laboratorium Struktur dan Bahan Jurusan Teknik Sipil Fakultas Teknik Universitas Palangka Raya. Tahapan penelitian yang dilakukan meliputi:

1. Pemeriksaan material agregat halus dan agregat kasar yang meliputi:
a. Pemeriksaan Berat Volume
b. Pemeriksaan Analisis Saringan
c. Pemeriksaan Kadar Air
d. Pemeriksaan Berat Jenis dan Penyerapan Air
e. Pemeriksaan Kadar Lumpur
f. Pemeriksaan Keausan Agregat Kasar dengan Mesin Abrasi Los Angeles

2. Pembuatan rancangan campuran (Mix Design) dengan SNI 03-2834-2000. Campuran rancangan dibuat untuk mutu beton normal $20 \mathrm{MPa}, 22,5 \mathrm{MPa}$, dan $25 \mathrm{MPa}$. Komposisi campuran mortar mengikuti bagian komposisi dari beton, sesuai dengan kuat tekan rencana masing-masing. Komposisi campuran untuk setiap rancangan mortar dan beton (air, semen, agregat halus, dan agregat kasar) ditampilkan pada Tabel 1, 2, 3, dan 4.

3. Pembuatan benda uji mortar dan beton meliputi penimbangan bahan/material, pengadukan bahan, dan pengecoran pada cetakan.

a. Pembuatan benda uji mortar dengan mix design dan perhitungan yang telah didapatkan, kemudian semua bahan yang telah ditimbang, diaduk sampai tercampur merata dan dimasukkan ke dalam cetakan benda uji mortar.

b. Pembuatan benda uji beton dilakukan dengan mencampur semua bahan yang telah ditimbang, kemudian dimasukkan ke dalam mesin pengaduk (mollen) hingga tercampur merata. Dilakukan pengujian pada campuran yang telah diaduk rata hingga didapatkan nilai slump sesuai rencana. Campuran beton segar dimasukkan ke dalam cetakan benda uji dan digetarkan dengan meja vibrator agar memenuhi cetakan dan tidak nampak gelembung udara pada permukaan beton.

4. Perawatan benda uji mortar dan beton dilakukan dengan merendam benda uji ke dalam bak rendaman air sesuai dengan umur pengujian yang direncanakan yaitu 28 hari.

5. Pengujian kuat tekan mortar dan beton dilakukan dengan mesin tekan (Compression Testing Machine). 
JURNAL KACAPURI

JURNAL KEILMUAN TEKNIK SIPIL

Volume 4 Nomor 2 Edisi Desember 2021

6. Menganalisa data kemudian membuat kesimpulan terhadap hasil penelitian yang telah didapatkan.

Tabel 1. Komposisi Campuran Mortar dan Beton Mutu 20 MPa FAS Variatif

\begin{tabular}{|c|c|c|c|c|c|c|c|c|c|c|}
\hline \multirow{3}{*}{ No } & \multirow{3}{*}{\multicolumn{2}{|c|}{$\begin{array}{c}\text { Variasi } \\
\text { Penambahan } \\
\text { Semen }\end{array}$}} & \multicolumn{8}{|c|}{ Komposisi Mutu 20 MPa } \\
\hline & & & \multirow{2}{*}{ FAS } & \multicolumn{2}{|c|}{ Semen $(\mathrm{kg})$} & \multicolumn{2}{|c|}{ Air (liter) } & \multicolumn{2}{|c|}{ Pasir (kg) } & \multirow{2}{*}{$\begin{array}{l}\text { Bt. Pecah } \\
\text { (kg) }\end{array}$} \\
\hline & & & & Beton & Mortar & Beton & Mortar & Beton & Mortar & \\
\hline 1 & VA4 & $+40 \%$ & 0,389 & 9,315 & 1,238 & 3,809 & 0,506 & 12,131 & 1,612 & 20,061 \\
\hline 2 & VA3 & $+30 \%$ & 0,419 & 8,650 & 1,163 & 3,809 & 0,512 & 12,131 & 1,632 & 20,061 \\
\hline 3 & VA2 & $+20 \%$ & 0,454 & 7,984 & 1,087 & 3,809 & 0,519 & 12,131 & 1,652 & 20,061 \\
\hline 4 & VA1 & $+10 \%$ & 0,495 & 7,319 & 1,010 & 3,809 & 0,526 & 12,131 & 1,674 & 20,061 \\
\hline 5 & & itrol & 0,545 & 6,654 & $\mathbf{0 , 9 3 0}$ & 3,809 & $\mathbf{0 , 5 3 3}$ & 12,131 & 1,696 & 20,061 \\
\hline 6 & VB1 & $-5 \%$ & 0,574 & 6,321 & 0,890 & 3,809 & 0,536 & 12,131 & 1,708 & 20,061 \\
\hline 7 & VB2 & $-10 \%$ & 0,606 & 5,988 & 0,849 & 3,809 & 4,350 & 12,131 & 1,721 & 20,061 \\
\hline
\end{tabular}

Sumber: Perhitungan Mix Design, 2020

Tabel 2. Komposisi Campuran Mortar dan Beton Mutu 22,5 MPa FAS Variatif

\begin{tabular}{|c|c|c|c|c|c|c|c|c|c|c|}
\hline \multirow{2}{*}{ No } & \multirow{2}{*}{$\begin{array}{c}\text { Variasi } \\
\text { Penambahan } \\
\text { Semen }\end{array}$} & \multirow{2}{*}{ FAS } & \multicolumn{2}{|c|}{ Semen (kg) } & \multicolumn{2}{|c|}{ Air (liter) } & \multicolumn{2}{|c|}{ Pasir (kg) } & \multirow{2}{*}{$\begin{array}{c}\text { Bt. Pecah } \\
\text { (kg) }\end{array}$} \\
\cline { 5 - 11 } & \multicolumn{2}{|c|}{} & Beton & Mortar & Beton & Mortar & Beton & Mortar & \\
\hline 1 & VA4 & $+40 \%$ & 0,371 & 9,763 & 1,293 & 3,807 & 0,504 & 11,853 & 1,569 & 20,022 \\
\hline 2 & VA3 & $+30 \%$ & 0,400 & 9,065 & 1,215 & 3,807 & 0,510 & 11,853 & 1,589 & 20,022 \\
\hline 3 & VA2 & $+20 \%$ & 0,433 & 8,368 & 1,136 & 3,807 & 0,517 & 11,853 & 1,610 & 20,022 \\
\hline 4 & VA1 & $+10 \%$ & 0,473 & 7,671 & 1,056 & 3,807 & 0,524 & 11,853 & 1,631 & 20,022 \\
\hline 5 & \multicolumn{2}{|c|}{ Kontrol } & $\mathbf{0 , 5 2 0}$ & $\mathbf{6 , 9 7 3}$ & $\mathbf{0 , 9 7 4}$ & $\mathbf{3 , 8 0 7}$ & $\mathbf{0 , 5 3 1}$ & $\mathbf{1 1 , 8 5 3}$ & $\mathbf{1 , 6 5 5}$ & $\mathbf{2 0 , 0 2 2}$ \\
\hline 6 & VB1 & $-5 \%$ & 0,547 & 6,625 & 0,932 & 3,807 & 0,535 & 11,853 & 1,667 & 20,022 \\
\hline 7 & VB2 & $-10 \%$ & 0,578 & 6,276 & 0,889 & 3,807 & 0,539 & 11,853 & 1,679 & 20,022 \\
\hline
\end{tabular}

Sumber: Perhitungan Mix Design, 2020

Tabel 3. Komposisi Campuran Mortar dan Beton Mutu 25 MPa FAS Variatif

\begin{tabular}{|c|c|c|c|c|c|c|c|c|c|c|}
\hline \multirow{3}{*}{ No } & \multirow{3}{*}{\multicolumn{2}{|c|}{$\begin{array}{c}\text { Variasi } \\
\text { Penambahan } \\
\text { Semen }\end{array}$}} & \multicolumn{8}{|c|}{ Komposisi Mutu 25 MPa } \\
\hline & & & \multirow{2}{*}{ FAS } & \multicolumn{2}{|c|}{ Semen $(\mathrm{kg})$} & \multicolumn{2}{|c|}{ Air (liter) } & \multicolumn{2}{|c|}{ Pasir (kg) } & \multirow{2}{*}{$\begin{array}{c}\text { Bt. Pecah } \\
\text { (kg) }\end{array}$} \\
\hline & & & & Beton & Mortar & Beton & Mortar & Beton & Mortar & \\
\hline 1 & VA4 & $+40 \%$ & 0,357 & 10,153 & 1,341 & 3,805 & 0,503 & 11,592 & 1,531 & 20,006 \\
\hline 2 & VA3 & $+30 \%$ & 0,385 & 9,428 & 1,261 & 3,805 & 0,509 & 11,592 & 1,551 & 20,006 \\
\hline 3 & VA2 & $+20 \%$ & 0,417 & 8,703 & 1,180 & 3,805 & 0,516 & 11,592 & 1,571 & 20,006 \\
\hline 4 & VA1 & $+10 \%$ & 0,455 & 7,978 & 1,097 & 3,805 & 0,523 & 11,592 & 1,594 & 20,006 \\
\hline 5 & Ko & atrol & 0,500 & 7,252 & 1,012 & 3,805 & $\mathbf{0 , 5 3 1}$ & 11,592 & 1,617 & 20,006 \\
\hline 6 & VB1 & $-5 \%$ & 0,526 & 6,890 & 0,968 & 3,805 & 0,535 & 11,592 & 1,629 & 20,006 \\
\hline 7 & VB2 & $-10 \%$ & 0,556 & 6,527 & 0,925 & 3,805 & 0,539 & 11,592 & 1,642 & 20,006 \\
\hline
\end{tabular}

Sumber: Perhitungan Mix Design, 2020 
Tabel 4. Komposisi Campuran Mortar dan Beton FAS Tetap 0,5 (Mutu 25 MPa)

\begin{tabular}{|c|c|c|c|c|c|c|c|c|c|c|}
\hline \multirow{3}{*}{ No } & \multirow{3}{*}{\multicolumn{2}{|c|}{$\begin{array}{c}\text { Variasi } \\
\text { Penambahan } \\
\text { Semen }\end{array}$}} & \multicolumn{8}{|c|}{ Komposisi FAS Tetap 0,5 } \\
\hline & & & \multirow{2}{*}{ FAS } & \multicolumn{2}{|c|}{ Semen $(\mathrm{kg})$} & \multicolumn{2}{|c|}{ Air (liter) } & \multicolumn{2}{|c|}{ Pasir (kg) } & \multirow{2}{*}{$\begin{array}{l}\text { Bt. Pecah } \\
(\mathrm{kg})\end{array}$} \\
\hline & & & & Beton & Mortar & Beton & Mortar & Beton & Mortar & \\
\hline 1 & VA4 & $+40 \%$ & 0,5 & 10,153 & 1,309 & 5,256 & 0,678 & 11,592 & 1,495 & 20,006 \\
\hline 2 & VA3 & $+30 \%$ & 0,5 & 9,428 & 1,238 & 4,893 & 0,642 & 11,592 & 1,522 & 20,006 \\
\hline 3 & VA2 & $+20 \%$ & 0,5 & 8,703 & 1,164 & 4,530 & 0,606 & 11,592 & 1,551 & 20,006 \\
\hline 4 & VA1 & $+10 \%$ & 0,5 & 7,978 & 1,089 & 4,168 & 0,569 & 11,592 & 1,582 & 20,006 \\
\hline 5 & \multicolumn{2}{|c|}{ Kontrol } & $\mathbf{0 , 5}$ & 7,252 & 1,012 & 3,805 & $\mathbf{0 , 5 3 1}$ & 11,592 & 1,617 & 20,006 \\
\hline 6 & VB1 & $-5 \%$ & 0,5 & 6,890 & 0,972 & 3,624 & 0,511 & 11,592 & 1,636 & 20,006 \\
\hline 7 & VB2 & $-10 \%$ & 0,5 & 6,527 & 0,932 & 3,443 & 0,492 & 11,592 & 1,655 & 20,006 \\
\hline
\end{tabular}

Sumber: Perhitungan Mix Design, 2020

\section{HASIL \& PEMBAHASAN}

\section{Pemeriksaan Karakteristik Bahan}

Data hasil pemeriksaan karakteristik bahan disajikan pada tabel berikut.

Tabel 5. Hasil Pemeriksaan Karakteristik Agregat Halus dan Agregat Kasar

\begin{tabular}{|c|c|c|c|c|}
\hline \multirow{2}{*}{ No } & \multirow{2}{*}{\multicolumn{2}{|c|}{ JENIS PEMERIKSAAN }} & \multicolumn{2}{|c|}{ Hasil Pemeriksaan } \\
\hline & & & Agregat Halus & Agregat Kasar \\
\hline 1 & \multicolumn{2}{|l|}{ Kadar Lumpur (\%) } & 1,880 & 0,288 \\
\hline 2 & \multicolumn{2}{|l|}{ Kadar air (\%) } & 0,200 & 0,452 \\
\hline \multirow{3}{*}{3} & \multirow{3}{*}{ Berat volume (kg/liter) } & Padat & 1,576 & 1,316 \\
\hline & & Goyangan & 1,563 & 1,237 \\
\hline & & Lepas & 1,518 & 1,219 \\
\hline \multirow{4}{*}{4} & \multicolumn{2}{|l|}{ Apparent Spec. Gravity } & 2,546 & 2,552 \\
\hline & \multicolumn{2}{|c|}{ Bulk Spec Gravity (kering) } & 2,486 & 2,494 \\
\hline & \multicolumn{2}{|l|}{ Bulk Spec Gravity (SSD) } & 2,509 & 2,517 \\
\hline & \multicolumn{2}{|l|}{ Penyerapan Air (\%) } & 0,939 & 0,913 \\
\hline 5 & \multicolumn{2}{|l|}{ Analisis Saringan } & Daerah Gradasi 2 & Uk. maks. $20 \mathrm{~mm}$ \\
\hline 6 & \multicolumn{2}{|l|}{ Keausan $(\%)$} & - & $35,440 \%$ \\
\hline
\end{tabular}

Sumber: Hasil Pengujian, 2020

Bahan material baik agregat halus maupun agregat kasar yang digunakan dalam pembuatan campuran mortar dan beton telah memenuhi syarat mutu agregat berdasarkan ASTM C.33 dan SII.0052 sehingga dapat digunakan dalam pembuatan campuran mortar dan beton mutu normal. 


\section{Karakteristik Pasir Sungai Kahayan}

1. Analisis Saringan

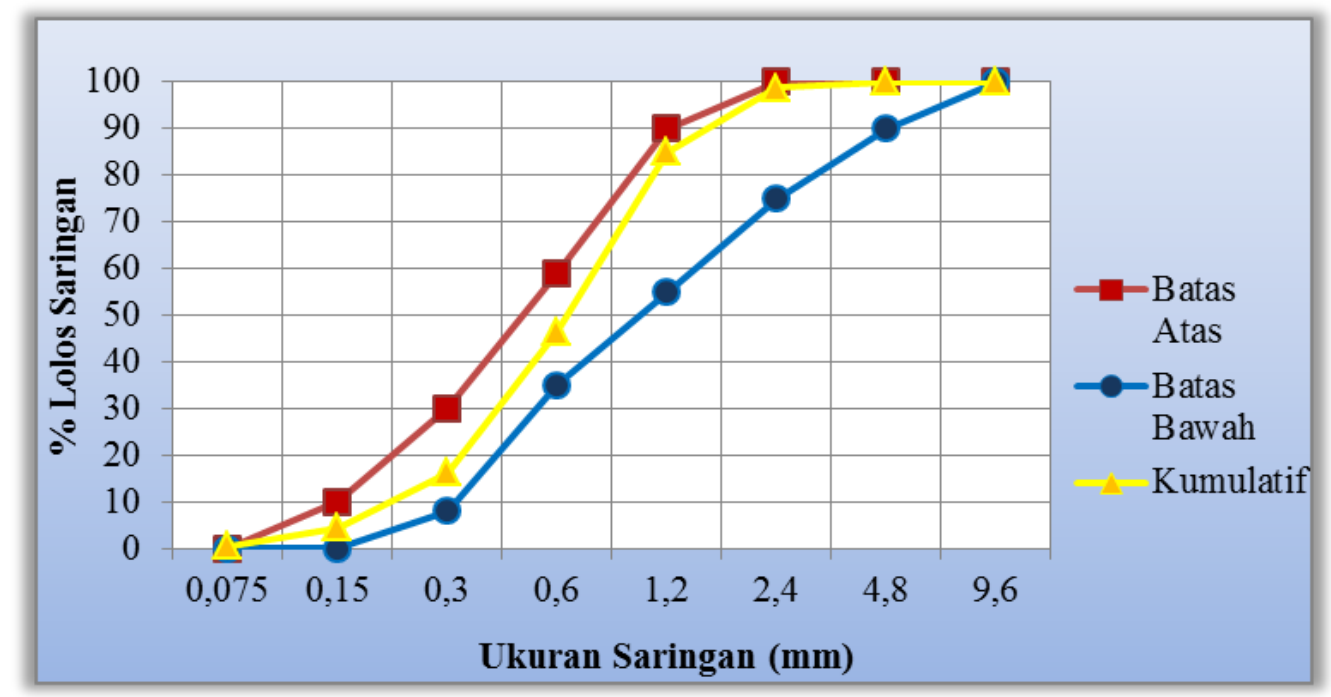

Gambar 1. Grafik Gradasi Agregat Halus (Pasir Sungai Kahayan) Zona 2

Pasir penelitian termasuk dalam gradasi Zona II (pasir agak kasar) dengan Modulus Halus Butir (MHB) sebesar 3,49 dan memenuhi syarat standar MHB yaitu antara 1,50 - 3,8 (Tjokrodimuljo, hal. 34, 2007). Pasir dengan gradasi pasir kasar (Zona I atau II) akan menghasilkan beton dengan nilai kuat tekan yang lebih besar dibandingkan dengan pasir yang lebih halus (Fattah, 2017). Pasir penelitian termasuk pasir yang cukup baik untuk campuran beton.

\section{Kadar Lumpur}

Kandungan kadar lumpur yang disyaratkan dalam standar SII.0052-80 tidak lebih dari 5\% $(\leq 5 \%)$ dan pasir penelitian dengan kadar lumpur sebesar 1,880\% memenuhi standar tersebut. Sehingga pasir penelitian bisa langsung digunakan tanpa harus dicuci terlebih dahulu.

\section{Modulus Halus Butir (MHB) / Fineness Modulus (FM)}

Nilai MHB pasir penelitian yang cukup tinggi dapat meningkatkan kelecakan beton segar sehingga memudahkan pengerjaan atau meningkatkan workability.

\section{Pengamatan Visual}

Pasir penelitian termasuk pasir silika, berwarna kuning kecoklatan, variasi ukuran butiran cukup baik, dan memiliki kestabilan butir yang rapuh, saat dicuci berulang-ulang akan menyebabkan pecahnya butiran atau degradasi butir yang membuat gradasi ukuran butir berubah.

\section{Hasil Uji Kuat Tekan Mortar dan Beton}

Uji kuat tekan dilakukan setelah perawatan benda uji selama 28 hari. Hasil uji kuat tekan mortar dan beton menggunakan Pasir Sungai Kahayan ditampilkan pada Tabel 6 dan 7. 
Tabel 6. Hasil Uji Kuat Tekan Mortar

\begin{tabular}{|c|c|c|c|c|c|c|c|c|c|}
\hline \multirow{4}{*}{ Variasi } & \multirow{4}{*}{$\begin{array}{l}\text { Umur } \\
\text { (hari) } \\
\end{array}$} & \multicolumn{6}{|c|}{ FAS Variatif } & \multirow{2}{*}{\multicolumn{2}{|c|}{$\begin{array}{c}\text { FAS Tetap 0,5 } \\
\text { Mutu } 25 \mathrm{MPa} \\
\end{array}$}} \\
\hline & & \multicolumn{2}{|c|}{ Mutu $20 \mathrm{MPa}$} & \multicolumn{2}{|c|}{ Mutu 22,5 MPa } & \multicolumn{2}{|c|}{ Mutu 25 MPa } & & \\
\hline & & \multirow{2}{*}{ FAS } & \multirow{2}{*}{\begin{tabular}{|c|}
$\begin{array}{c}\text { Kuat } \\
\text { Tekan }\end{array}$ \\
(MPa) \\
\end{tabular}} & \multirow{2}{*}{ FAS } & $\begin{array}{l}\text { Kuat } \\
\text { Tekan }\end{array}$ & \multirow{2}{*}{ FAS } & $\begin{array}{l}\text { Kuat } \\
\text { Tekan }\end{array}$ & \multirow{2}{*}{ FAS } & \multirow{2}{*}{$\begin{array}{r}\text { Kuat } \\
\text { Tekan } \\
\text { (MPa) } \\
\end{array}$} \\
\hline & & & & & (MPa) & & & & \\
\hline VA 4 & 28 & 0 , & 22,918 & 0,371 & & & 27,375 & & 25,168 \\
\hline & 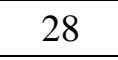 & & & & & & & & \\
\hline VA 2 & 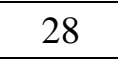 & 0,454 & & 0,433 & & & & 0,500 & \\
\hline VA 1 & 28 & 0,495 & 17 & 0,473 & 20,690 & 0,455 & & 0,500 & 396 \\
\hline Kontrc & 28 & 0,545 & & 0,520 & & & & 0,500 &, 462 \\
\hline VB 1 & 28 & 0,574 & 14,982 & 0,547 & 18,462 & 0,526 & 18,589 & 0,500 & 14,642 \\
\hline VB 2 & 28 & 0,606 & 14,961 & 0,578 & 16,234 & 0,556 & 18,292 & 0,500 & 14,345 \\
\hline
\end{tabular}

Tabel 7. Hasil Uji Kuat Tekan Beton

\begin{tabular}{|c|c|c|c|c|c|c|c|c|c|}
\hline \multirow{4}{*}{ Variasi } & \multirow{4}{*}{$\begin{array}{l}\text { Umur } \\
\text { (hari) }\end{array}$} & \multicolumn{6}{|c|}{ FAS Variatif } & \multirow{2}{*}{\multicolumn{2}{|c|}{$\begin{array}{r}\text { FAS Tetap 0,5 } \\
\text { Mutu } 25 \mathrm{MPa}\end{array}$}} \\
\hline & & \multicolumn{2}{|c|}{ Mutu 20 MPa } & \multicolumn{2}{|c|}{ Mutu 22,5 MPa } & \multicolumn{2}{|c|}{ Mutu 25 MPa } & & \\
\hline & & \multirow{2}{*}{ FAS } & \multirow{2}{*}{$\begin{array}{c}\begin{array}{c}\text { Kuat } \\
\text { Tekan }\end{array} \\
\text { (MPa) }\end{array}$} & \multirow{2}{*}{ FAS } & \multirow{2}{*}{$\begin{array}{c}\begin{array}{c}\text { Kuat } \\
\text { Tekan }\end{array} \\
\text { (MPa) }\end{array}$} & \multirow{2}{*}{ FAS } & \multirow{2}{*}{$\begin{array}{c}\begin{array}{c}\text { Kuat } \\
\text { Tekan }\end{array} \\
\text { (MPa) } \\
\end{array}$} & \multirow{2}{*}{ FAS } & \multirow{2}{*}{$\begin{array}{c}\begin{array}{c}\text { Kuat } \\
\text { Tekan }\end{array} \\
\text { (MPa) }\end{array}$} \\
\hline & & & & & & & & & \\
\hline VA 4 & 28 & & 28,436 & & & & & & 26,172 \\
\hline VA 3 & 28 & 0,419 & 27 & 0,400 & 27 & 0,385 & 28 & 0,500 & 748 \\
\hline VA 2 & 28 & 0,454 & 22,918 & 0,433 & 23 & 0,417 & 27, & 0,500 & 22,918 \\
\hline VA 1 & 28 & 0,495 & 20,372 & 0,473 & 22 & 0,455 & 25 & 0,500 & 19,240 \\
\hline Kontrol & 28 & 0,545 & 16,552 & 0,520 & 17 & 0,500 & 19 & 0,500 & 18,816 \\
\hline VB 1 & 28 & 0,574 & & & & & & 0,500 & 17,825 \\
\hline VB 2 & 28 & 0,606 & 10,639 & 0,578 & 11,601 & 0,556 & 13,157 & 0,500 & 16,977 \\
\hline
\end{tabular}

Sumber: Hasil Pengujian, 2020

Kuat tekan yang ditargetkan untuk mortar dan beton mutu $20 \mathrm{MPa}$ adalah 32 $\mathrm{MPa}$, untuk mutu 22,5 $\mathrm{MPa}$ adalah $34,5 \mathrm{MPa}$, dan untuk mutu $25 \mathrm{MPa}$ adalah 37 $\mathrm{MPa}$. Dengan hasil kuat tekan yang diperoleh baik pada mortar maupun beton, terlihat bahwa belum ada satupun kuat tekan yang mencapai kuat tekan target. Namun, dapat dilihat bahwa dengan upaya penambahan semen sampai batas tertentu dan pengurangan nilai FAS dapat meningkatkan kuat tekan mortar dan beton. 


\section{Analisis Pengaruh FAS dan Kadar Semen}

1. Pengaruh FAS terhadap Kuat Tekan

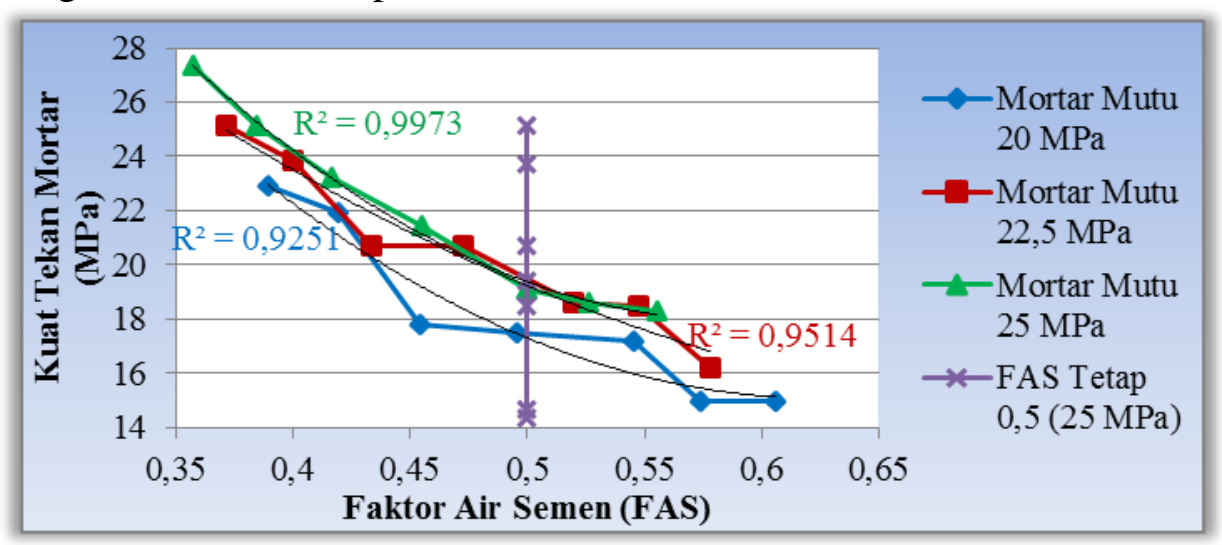

Gambar 2. Grafik Hubungan Kuat Tekan Mortar dengan FAS

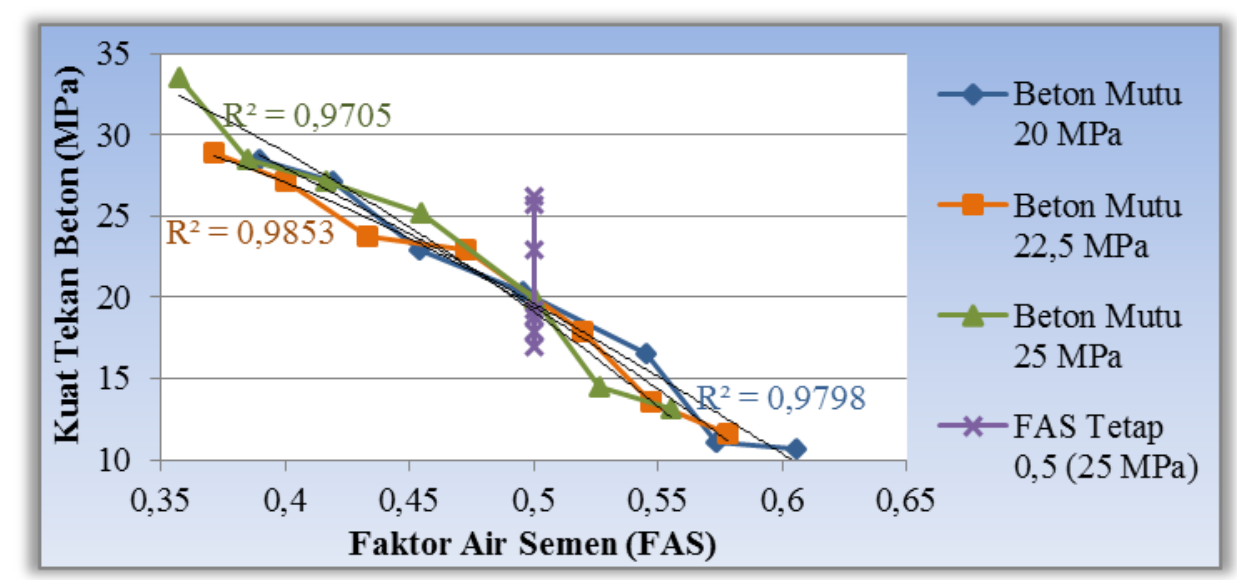

Gambar 3. Grafik Hubungan Kuat Tekan Beton dengan FAS

\section{FAS Variatif}

Gambar 2 dan 3 menunjukkan hubungan antara kuat tekan mortar dan beton dengan FAS, yaitu semakin rendah nilai FAS, semakin tinggi nilai kuat tekan yang dihasilkan. Faktor Air Semen (Water Cement Ratio) merupakan parameter kunci dalam pembuatan beton mutu tinggi, terlihat bahwa FAS yang rendah dapat menghasilkan kuat tekan yang tinggi. Setiap penurunan nilai FAS 0,1 akan meningkatkan kuat tekan rata-rata mortar sebesar 4,63 $\mathrm{MPa}$ dan kuat tekan ratarata beton sebesar 8,19 MPa. Nilai FAS yang semakin rendah tidak selalu akan meningkatkan kuat tekan beton, disisi lain dapat menyebabkan kesulitan dalam pengerjaan/workability dan menyulitkan proses pemadatan yang berakibat pada menurunnya kuat tekan. Penurunan nilai FAS sebaiknya dibatasi ketika sudah mulai dirasakan kesulitan pengerjaan yaitu pada nilai FAS 0,4. Sebaliknya, semakin tinggi nilai FAS akan menghasilkan kuat tekan yang rendah. Setiap peningkatan nilai FAS 0,1 akan menurunkan kuat tekan rata-rata mortar sebesar 3,07 MPa dan kuat tekan rata-rata beton sebesar 10,92 MPa. Peningkatan FAS mengakibatkan penurunan kuat tekan yang cukup besar pada mortar maupun beton, sehingga tidak disarankan dalam pembuatan campuran diterapkan perlakuan peningkatan FAS. 


\section{FAS Tetap}

Pada FAS tetap, kuat tekan mengalami peningkatan walaupun dilakukan perlakuan FAS konstan sebesar 0,5. Hal ini disebabkan karena adanya bantuan penambahan semen pada variasi campuran mortar dan beton. Apabila dibandingkan dengan hubungan pada FAS variatif, terlihat bahwa kontribusi nilai FAS lebih berpengaruh dibandingkan dengan penambahan semen terhadap peningkatan kuat tekan. Selisih perbedaan peningkatan antara penurunan FAS dan penambahan kadar semen dapat dinyatakan sebagai sumbangan kekuatan akibat penurunan nilai FAS. Setiap selisih kenaikan kuat tekan FAS 0,1 terjadi sumbangan kekuatan rata-rata sebesar 2,048 $\mathrm{MPa}$ pada mortar dan 5,051 MPa pada beton.

2. Pengaruh Kadar Semen terhadap Kuat Tekan

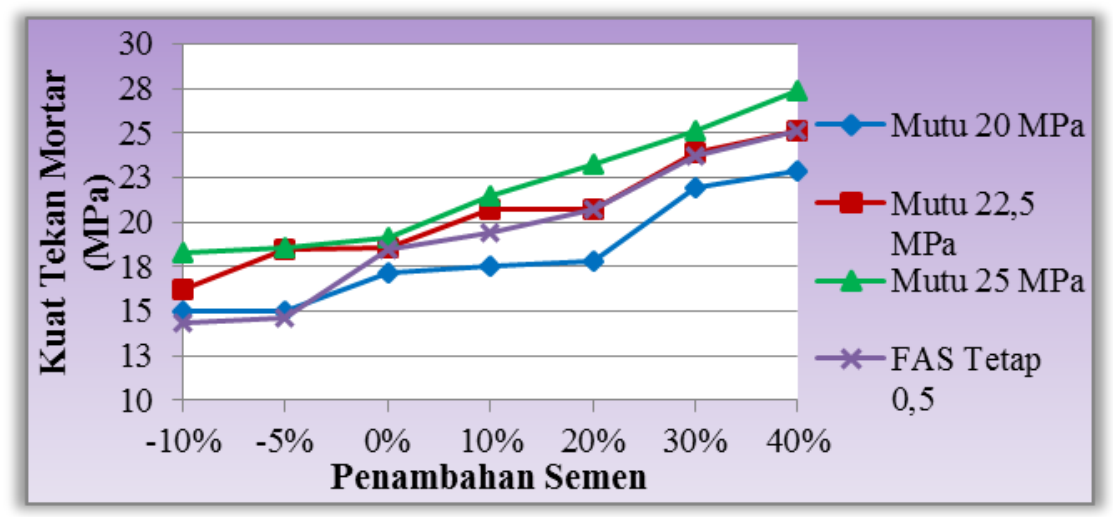

Gambar 4. Grafik Hubungan Kuat Tekan Mortar dengan Penambahan Semen

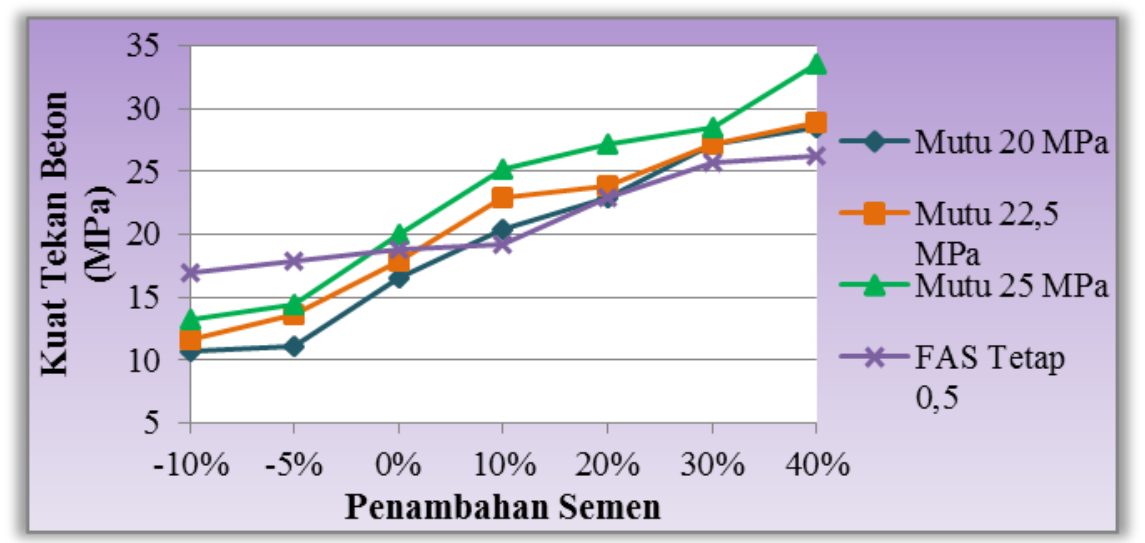

Gambar 5. Grafik Hubungan Kuat Tekan Beton dengan Penambahan Semen

\section{FAS Variatif}

a. Pada kondisi ini jumlah air campuran tetap, jumlah semen bertambah.

b. Peningkatan kekuatan seiring penambahan semen yang sama dan penurunan FAS menghasilkan kuat tekan yang lebih besar daripada kondisi FAS tetap.

c. Semakin bertambahnya semen diiringi penurunan FAS akan menyebabkan berkurangnya workability. Pada penambahan semen 30\% dan perubahan FAS menjadi 0,4 mulai terasa kesulitan/rendahnya workabilitas yang dapat 
menyebabkan gagalnya sebuah pemadatan beton, misalnya menjadi beton keropos.

d. Setiap $1 \%$ penambahan semen akan meningkatkan kuat tekan rata-rata mortar sebesar 0,172 MPa dan beton sebesar 0,304 MPa pada FAS variatif.

e. Pada kondisi ini terjadi dua sumbangan peningkatan kekuatan, yaitu dari penambahan semen dan penurunan FAS.

f. Penambahan kandungan semen memang menghasilkan peningkatan pada kuat tekan, terutama pada usia awal beton, namun dengan faktor lain yang ditetapkan standar, FAS memiliki efek yang lebih besar pada kekuatan tekan mortar maupun beton (Wasserman, 2009 dalam LeBow, 2018).

g. Pengurangan jumlah semen pada kondisi ini menyebabkan menurunnya kuat tekan rata-rata sebesar $0,090 \mathrm{MPa}$ setiap $1 \%$ pengurangan semen pada mortar, dan $0,315 \mathrm{MPa}$ setiap $1 \%$ pengurangan semen pada beton.

FAS Tetap

a. Pada kondisi ini terjadi peningkatan semen diiringi penambahan air.

b. Pengaruh penambahan semen pada kuat tekan mortar dan beton membuktikan bahwa penambahan semen memberikan peningkatan kekuatan.

c. Pada kondisi ini, setiap $1 \%$ penambahan semen akan meningkatkan kuat tekan rata-rata mortar sebesar $0,168 \mathrm{MPa}$ dan beton sebesar $0,184 \mathrm{MPa}$.

d. Namun, penambahan semen ini memiliki kekurangan dalam hal ekonomis bahan. Penggunaan semen yang terlalu banyak akan menghasilkan mortar dan beton yang tidak ekonomis dan mahal harganya walaupun memiliki kuat tekan yang tinggi.

e. Selain dapat meningkatkan kuat tekan beton dan workability, penambahan pasta semen juga berguna sebagai pengisi rongga dalam beton dan menutupi agregat serta memisahkannya untuk mengurangi gesekan partikel antar agregat (Yurdakul, 2013).

f. Pada kondisi ini sumbangan kekuatan hanya dihasilkan dari penambahan semen.

g. Pengurangan jumlah semen pada kondisi ini menyebabkan menurunnya kuat tekan rata-rata sebesar $0,412 \mathrm{MPa}$ setiap $1 \%$ pengurangan semen pada mortar, dan 0,184 MPa setiap $1 \%$ pengurangan semen pada beton.

h. Pengurangan jumlah semen mengakibatkan penurunan kuat tekan yang cukup besar sehingga tidak disarankan untuk dilakukan pada campuran mortar maupun beton.

\section{Pengaruh Rasio P/C terhadap Kuat Tekan}

Perlakuan penambahan semen (FAS tetap dan variatif) menyebabkan perubahan rasio berat pasir terhadap semen (p/s). Hubungan antara kuat tekan dengan rasio pasir/semen (p/s) ditunjukkan pada Gambar 6 dan 7. 


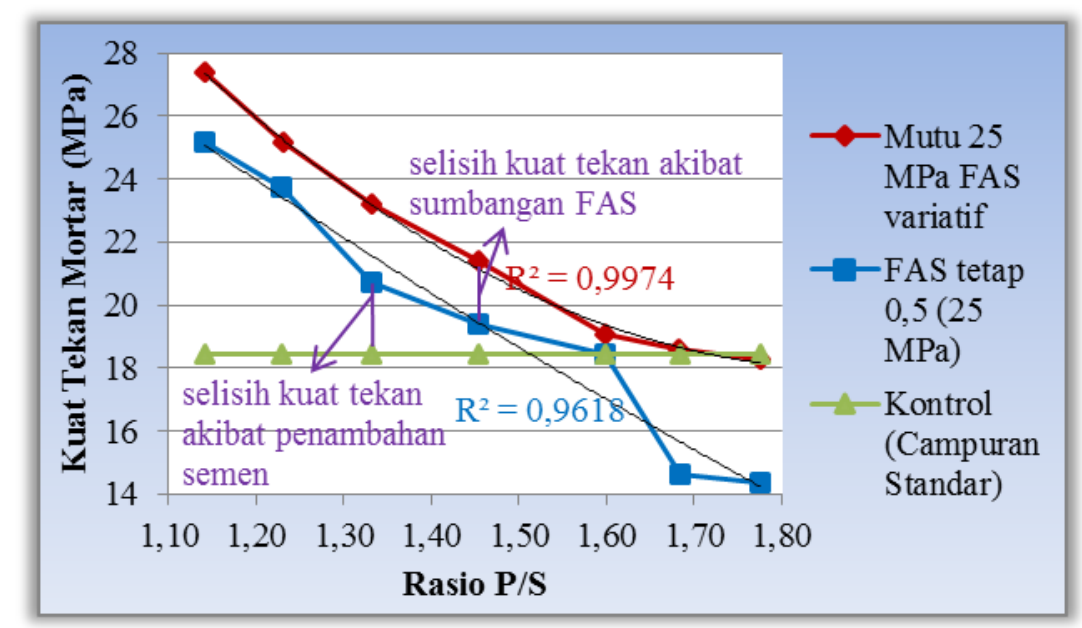

Gambar 6. Grafik Hubungan Kuat Tekan Mortar dengan Rasio Pasir/Semen

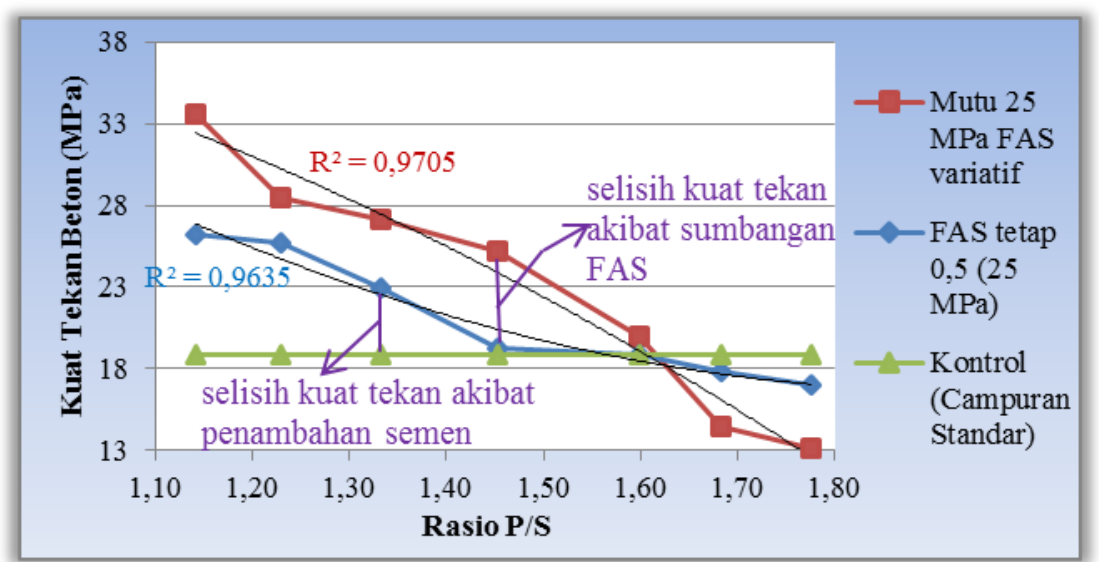

Gambar 7. Grafik Hubungan Kuat Tekan Beton dengan Rasio Pasir/Semen

\section{FAS Variatif}

Pada hubungan antara kuat tekan dengan rasio pasir/semen (p/s) terlihat perubahan komposisi p/s pada setiap kenaikan kuat tekan yang disebabkan oleh: (1) penambahan semen dan (2) pengurangan FAS. Dari hubungan tersebut diketahui bahwa dua faktor di atas yang menyebabkan terjadinya peningkatan kuat tekan mortar dan beton. Pada kondisi ini (baik mortar dan beton) terjadi gabungan peningkatan kekuatan akibat dari penurunan FAS dan perubahan rasio p/s. Setiap penurunan rasio p/s 0,1 terjadi peningkatan kuat tekan rata-rata mortar sebesar 1,814 MPa dan kuat tekan rata-rata beton sebesar 2,974 MPa. Selain penambahan semen, pengurangan jumlah semen tampak berpengaruh pada kuat tekan. Berkurangnya jumlah semen dalam komposisi mortar dan beton menyebabkan rasio $\mathrm{p} / \mathrm{s}$ meningkat yang mengakibatkan menurunnya kuat tekan mortar dan beton. Pada kondisi FAS variatif, setiap kenaikan rasio p/s 0,1 akan menurunkan kuat tekan rata-rata mortar sebesar 0,455 $\mathrm{MPa}$ dan beton sebesar 3,825 MPa.

\section{FAS Tetap}

Pada kondisi ini sumbangan peningkatan kekuatan hanya disebabkan oleh penurunan rasio $\mathrm{p} / \mathrm{s}$. Setiap penurunan rasio p/s 0,1 akan meningkatkan kuat tekan 
rata-rata mortar sebesar 1,471 $\mathrm{MPa}$ dan kuat tekan rata-rata beton sebesar 1,611 MPa. Peningkatan kekuatan pada kondisi ini lebih rendah dibandingkan pada FAS variatif. Selisih peningkatan kekuatan antara FAS variatif dan FAS tetap adalah sumbangan dari perubahan FAS. Selisih kuat tekan rata-rata pada mortar sebesar 1,766 MPa dan pada beton sebesar 4,267 MPa. Sebaliknya, peningkatan rasio p/s pada komposisi mortar dan beton menyebabkan kuat tekan menurun. Pada kondisi ini, setiap peningkatan rasio $\mathrm{p} / \mathrm{s}$ 0,1 terjadi penurunan kuat tekan rata-rata mortar sebesar 2,314 MPa dan kuat tekan rata-rata beton sebesar 1,036 MPa. Pada grafik Gambar 6 dan 7 tidak terlihat adanya nilai optimum dari rasio pasir terhadap semen, baik itu pada kondisi FAS variatif maupun FAS tetap. Kondisi tersebut mengindikasikan penambahan semen hanya menyumbangkan peningkatan kuat tekan yang kecil.

\section{Hubungan Kuat Tekan Mortar terhadap Kuat Tekan Beton}

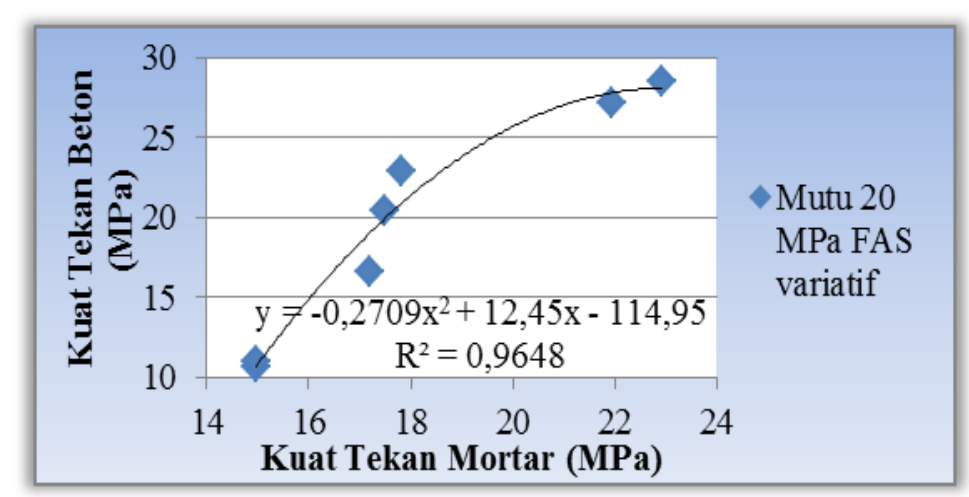

Gambar 8. Grafik Hubungan Kuat Tekan Mortar terhadap Kuat Tekan Beton Mutu 20 MPa FAS Bervariasi

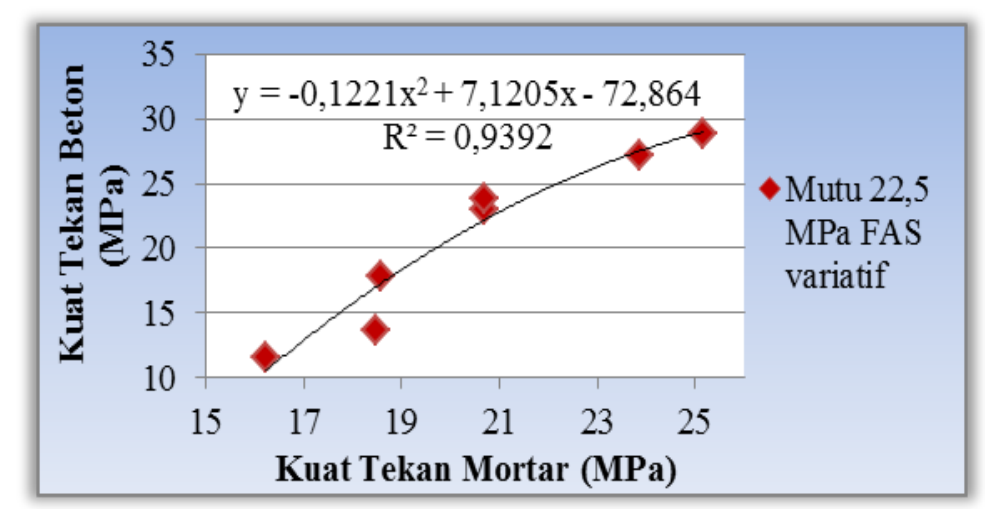

Gambar 9. Grafik Hubungan Kuat Tekan Mortar terhadap Kuat Tekan Beton Mutu 22,5 MPa FAS Bervariasi 


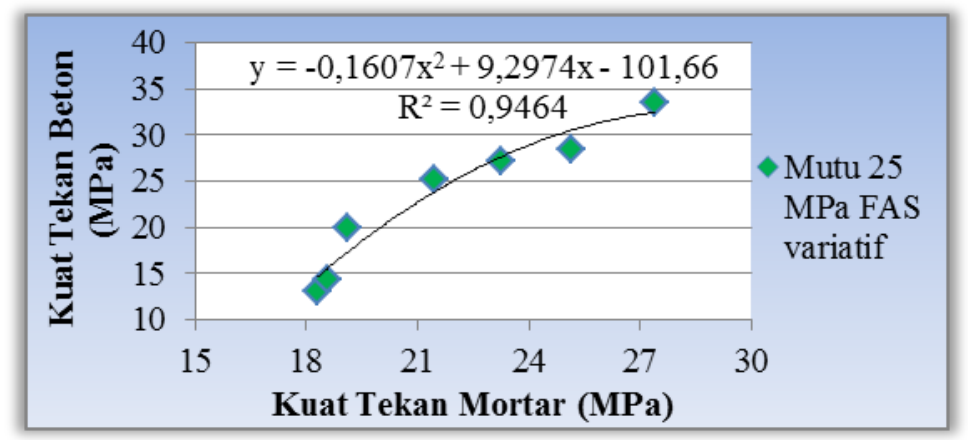

Gambar 10. Grafik Hubungan Kuat Tekan Mortar terhadap Kuat Tekan Beton Mutu 25 MPa FAS Bervariasi

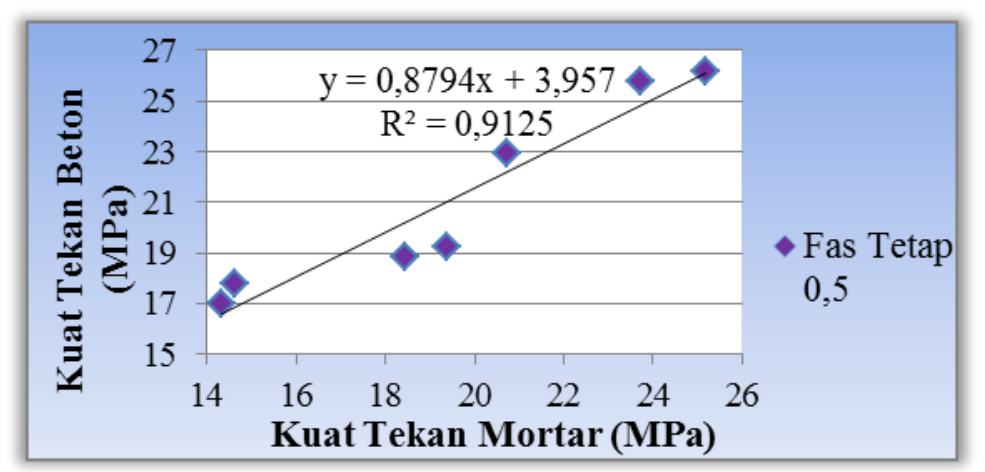

Gambar 11. Grafik Hubungan Kuat Tekan Mortar terhadap Kuat Tekan Beton FAS Tetap 0,5

Pada Gambar 8, 9, dan 10 yang berupa hubungan FAS variatif tampak bahwa garis hubungan terwakili/representatif membentuk garis polynomial dikarenakan ada dua sumbangan kekuatan yaitu perubahan rasio $\mathrm{p} / \mathrm{s}$ dan perubahan FAS. Pada Gambar 11 yang berupa hubungan FAS tetap, garis hubungannya terwakili oleh garis linear karena hanya mendapatkan sumbangan kekuatan dari perubahan rasio p/s saja. Hubungan antara kuat tekan mortar dengan kuat tekan beton pada penelitian ini dianalisis menggunakan analisis korelasi. Nilai koefisien korelasi (R) yang diperoleh pada hubungan antara kuat tekan mortar dengan kuat tekan beton antara lain 0,982 pada mutu $20 \mathrm{MPa}, 0,969$ pada mutu 22,5 $\mathrm{MPa}, 0,973$ pada mutu $25 \mathrm{MPa}$ dan 0,955 pada FAS tetap. Koefisien determinasi $\left(\mathrm{R}^{2}\right)$ yang diperoleh antara lain 0,9648 pada mutu $20 \mathrm{MPa}, 0,9392$ pada mutu 22,5 MPa, 0,9464 pada mutu $25 \mathrm{MPa}$, dan 0,9125 pada FAS tetap. Nilai koefisien korelasi yang tinggi menunjukkan bahwa kuat tekan mortar dan beton memiliki hubungan linear yang kuat dan arah hubungan yang positif atau searah. Yang berarti semakin tinggi kuat tekan mortar akan semakin tinggi kuat tekan beton. Nilai koefisien determinasi yang tinggi menunjukkan bahwa kuat tekan beton (variabel Y) dapat diterangkan dengan kuat tekan mortar (variabel X). Hal tersebut mengindikasikan bahwa kekuatan beton bisa dinyatakan oleh kekuatan mortar karena kuatnya nilai koefisien determinasi yang diperoleh. Untuk mengetahui kekuatan beton dapat dilakukan hanya dengan membuat mortarnya saja. Hal ini sejalan dengan penelitian yang dilakukan sebelumnya oleh Camoes, Aguiar, \& Jalali (2005). Dengan hanya melakukan pembuatan benda uji mortar dapat 
diperkirakan nantinya kuat tekan beton yang diinginkan tanpa harus membuat benda uji beton.

\section{PENUTUP}

\section{Kesimpulan}

Dari hasil pengujian, analisis data, dan pembahasan dapat ditarik kesimpulan sebagai berikut.

1. Karakteristik pasir Sungai Kahayan yang diperoleh dari pemeriksaan memenuhi syarat mutu agregat berdasarkan ASTM C.33 dan SII.0052 sehingga dapat digunakan dalam pembuatan campuran mortar dan beton mutu normal. Secara visual pasir penelitian termasuk pasir silika, berwarna kuning kecoklatan, variasi ukuran butiran cukup baik, dan memiliki kestabilan butir yang rapuh, saat dicuci berulang-ulang akan menyebabkan pecahnya butiran atau degradasi butir yang membuat gradasi ukuran butir berubah.

2. Kuat tekan beton dan mortar dihasilkan seiring dengan perubahan nilai FAS dan kadar semen pada mutu $20 \mathrm{MPa}, 22,5 \mathrm{MPa}$, dan $25 \mathrm{MPa}$.

a. Pada mortar FAS variatif dihasilkan kuat tekan sebesar 22,918 $\mathrm{MPa}$, $25,168 \mathrm{MPa}$, dan 27,375 MPa.

b. Pada mortar FAS tetap dihasilkan kuat tekan sebesar 25,168 MPa.

c. Pada beton FAS variatif dihasilkan kuat tekan sebesar 28,436 MPa, 28,860 $\mathrm{MPa}$, dan 33,529 MPa.

d. Pada beton FAS tetap dihasilkan kuat tekan sebesar 26,172 MPa.

3. FAS memiliki pengaruh yang cukup signifikan pada kuat tekan mortar dan beton. Nilai FAS maksimum yang dianjurkan adalah 0,5 dan batas terendahnya dimana terjadi kesulitan pengerjaan (workability rendah) pada nilai FAS rata-rata 0,4 . Pengaruh perubahan FAS memiliki sumbangan yang lebih besar pada peningkatan kuat tekan. Setiap selisih kenaikan FAS 0,1 terjadi sumbangan kekuatan rata-rata sebesar 2,048 MPa pada mortar dan 5,051 MPa pada beton.

4. Hubungan yang diperoleh antara kuat tekan mortar dan kuat tekan beton menghasilkan nilai korelasi yang tinggi dan bernilai positif yang menunjukkan bahwa semakin tinggi kuat tekan mortar maka semakin tinggi kuat tekan beton. Selain itu diketahui bahwa kekuatan beton bisa dinyatakan oleh kekuatan mortar karena kuatnya nilai koefisien determinasi yang diperoleh.

\section{Saran}

1. Berdasarkan penelitian-penelitian lalu yang telah dilakukan, terdapat kesulitan dalam mencapai target kuat tekan beton normal menurut standar SNI dengan pasir jenis ini. Maka, pada penelitian selanjutnya perlu dilakukan antara lain:

a. Terhadap campuran standar SNI 03-2834-2000 perlu ditambahkan 10\% maksimum kadar semen dengan FAS 0,4 atau pada saat sudah mulai dicapai kesulitan pengerjaan.

b. Untuk pekerjaan pembetonan lapangan dengan rancangan campuran SNI menggunakan pasir Sungai Kahayan sebaiknya digunakan bahan tambah (admixture). 
c. Melakukan upaya modifikasi/perubahan komposisi pada kadar agregat kasar terhadap agregat halus maupun agregat total terhadap semen pada jumlah semen yang cukup.

2. Pentingnya pemadatan pembetonan menggunakan mesin penggetar.

3. Penggunaan campuran rancangan beton SNI 03-2834-2000 dengan pasir Sungai Kahayan perlu didahului campuran uji (trial mix) dan campuran kerja (job-mix formula) yang teliti sebelum diterapkan untuk praktek konstruksi beton struktural di lapangan.

\section{DAFTAR PUSTAKA}

Anonim. 2000. SNI 03-2834-2000 Tata Cara Pembuatan Rencana Campuran Beton Normal. Badan Standarisasi Nasional.

Camoes, A., B. Aguiar, S. Jalali. 2005. Estimating Compressive Strength of Concrete by Mortar Testing. International Conference on Concrete for Structures. (05): 121-127.

Fattah, A., \& Abdul Nabi. 2017. Pengaruh Zona Pasir terhadap Kuat Tekan beton Normal. Prosiding Seminar Hasil Penelitian (SNP2M). (pp): 107-112.

LeBow, Caleb J. 2018. Effect of Cement Content on Concrete Performance. Theses and Dissertations. Civil Engineering University of Arkansas, Fayetteville.

Li, Zongjin. 2011. Advanced Concrete Technology. New Jersey: John Wiley and Sons, Inc.

Mariati. 2015. Karakteristik Pasir Sungai Kahayan Sebagai Material Pembuatan Beton. Laporan Tugas Akhir. Jurusan Teknik Sipil Fakultas Teknik. Universitas Palangka Raya: Palangka Raya.

Meilawaty, Okta. 2017. Buku Panduan Praktikum Beton. Jurusan Teknik Sipil Fakultas Teknik. Universitas Palangka Raya: Palangka Raya.

Mulyono, Tri. 2004. Teknologi Beton. Yogyakarta: Penerbit ANDI.

Tjokrodimuljo, Kardiyono. 2007. Teknologi Beton. Yogyakarta: Biro Penerbit Teknik Sipil Universitas Gadjah Mada.

Yurdakul, Ezgi. 2013. Proportioning for Performance - Based Concrete Pavement Mixtures. Graduate Theses and Dissertations. Civil, Construction, and Environmental Engineering Iowa State University. 